\title{
Kerja Sama Guru dan Orang Tua dalam Membina Akhlak Siswa
}

\author{
Rosidatul Haq ${ }^{1}$, Ahmad Kosasih ${ }^{2}$ \\ rosidatulhaq5@gmail.com¹, ahmadkosasihTanjung@gmail.com² \\ Universitas Negeri Padang ${ }^{1,2}$
}

\begin{tabular}{l}
\hline ARTICLE INFO \\
\hline Article history: \\
Received, 24 September \\
2021 \\
Revised, 11 November \\
2021 \\
Accepted, 30 November \\
2021 \\
\hline
\end{tabular}

\section{Keywords:}

Kerja Sama, Guru, Orang

Tua Akhlak

\section{Clonflict of Interest:}

None

\section{Funding:}

None

\begin{abstract}
Keluarga merupakan tempat pertama bagi anak dalam menerima pendidikan, yaitu dalam pergaulan hidupnya sehari-hari. Sehingga dalam hal ini peranan orang tua sangat menentukan terhadap pembentukan sikap dan prilaku anak agar tumbuh dan berkembang menjadi anak yang berakhlak mulia. Dalam pembentukan akhlak seorang anak diperlukan kerja sama antara keluarga (orang tua) dan sekolah (guru). Pembentukan akhlak siswa berlangsung secara berangsur-angsur dan berkesinambungan antara orang tua dan guru. Dalam penelitian ini menggunakan jenis penelitian lapangan (field research) yang bertujuan untuk mengetahui prilaku siswa yang terjadi dilapangan. Lokasi penelitian ini adalah di SMA Negeri 1 Gunung Tuleh yang terletak di kenagarian Rabi Jonggor kecamatan Gunung Tuleh, kabupaten Pasaman Barat. Informan dalam penelitian ini adalah kepala sekolah, guru pendidikan agama islam (PAI) dan orang tua siswa SMA Negeri 1 Gunung Tuleh. Teknik pengumpulan data yang digunakan yaitu observasi, wawancara, dokumentasi. Penelitian ini menghasilkan kerja sama yang dilakukan oleh guru dan orang tua dalam pembinaan akhlak siswa pada SMA Negeri 1 Gunung Tuleh Kecamatan Gunung Tuleh Kabupaten Pasaman Barat yaitu orang tua melakukan konsultasi langsung pada guru atau sebaliknya guru melakukan konsultasi kepada orang tua serta orang tua melakukan kunjungan ke sekolah.
\end{abstract}

Corresponding Author: Rosidatul Haq, Department Islamic Education, Faculty of Social Science, Universitas Negeri Padang, Indonesia, Email: rosidatulhaq5@gmail.com Phone: +62822-8504-3251

\section{Pendahuluan}

Keluarga merupakan tempat pertama bagi anak dalam menerima pendidikan, yaitu dalam pergaulan hidupnya sehari-hari. Sehingga dalam hal ini peranan orang tua sangat menentukan terhadap pembentukan sikap dan prilaku anak agar tumbuh dan berkembang menjadi anak yang berakhlak mulia. Keluarga juga suatu lembaga pembinaan kehidupan anak yang pertama dalam menentukan bahagia atau tidaknya kehidupan mereka di kemudian hari.

Orang tua (ayah/ibu) memiliki peran utama baik dalam memberikan pendidikan maupun bimbingan kepada anak agar anak tidak mudah terpengaruh oleh lingkungan yang tidak baik setelah dewasa nanti. Oleh karena itu anak harus menjadi perhatian utama orang tua dalam keluarga. Memelihara dan mendidik anak semenjak kecil sampai anak menjadi dewasa 
Rosidatul Haq dan Ahmad Kosasih: Kerja Sama Guru dan Orang Tua dalam Membina Akhlak...

merupakan tanggung jawab orang tua, keluarga merupakan lingkungan yang sangat menentukan dalam pembentukan kepribadian dan akhlak anak, juga dalam lingkungan inilah dibina dan diarahkan.

Selanjutnya dapat dipahami bahwa Pembentukan akhlak berlangsung secara berangsurangsur dan berkesinambungan. Oleh karena itu pembentukan akhlak merupakan suatu proses yang kalau berlangsung dengan baik maka akan menghasilkan suatu akhlak yang baik begitu sebaliknya, apabila berlangsung dengan tidak baik maka akan menghasilkan akhlak yang tidak baik pula.

Pembentukan akhlak anak berawal dari pendidkan dirumahnya. Anak adalah amanah ditangan ibu dan bapaknya, hatinya masih suci ibarat permata yang mahal harganya, maka apabila dibiasakan dengan sesuatu yang baik dan didik, maka ia akan besar dengan sifat-sifat baik serta akan berbahagia dunia dan akhirat sebaliknya jika terbiasa dengan adat buruk tidak dipedulikan seperti halnya hewan ia akan hancur binasa.

Oleh karena itu anak perlu dimasukkan ke sekolah supaya anak bisa belajar dan memperoleh apa yang belum didapatkannya di dalam keluarga, dengan harapan mampu menseimbangkan dan mengamalkan apa yang diperoleh di bangku sekolah maupun dilingkungan keluarga dalam kehidupan sehari-hari.

Paraman Ampalu merupakan salah satu desa di kecamatan Gunung Tuleh kabupaten Pasaman Barat yang memiliki beberapa sekolah didalamnya mulai dari tingkat sekolah dasar hingga sekolah menengah atas. Salah satunya ialah SMA Negeri 1 Gunung Tuleh. SMA Negeri 1 Gunung Tuleh merupakan tempat peneliti akan melaksanakan penelitian, selama melakukan observasi lapangan tepatnya pada saat praktek lapangan peneliti mengamati banyak siswa khususnya kelas dua belas karena, peneliti berkesempatan untuk mengajar di kelas XII dan melihat langsung tingkah laku dan kebiasaan-kebiasaan yang sering terjadi di kelas maupun di lingkungan masyarakat. Pada dasarnya siswa belajar dengan baik serta mengikuti aturan-aturan yang berlaku disekolah, namun beberapa siswa berprilaku sebaliknya tidak mau belajar dan mengabaikan aturan-aturan yang berlaku disekolah. Contoh perbuatan yang melanggar tata tertib sekolah tersebut adalah terlambat datang ke sekolah, keluar masuk kelas, ribut dan kurang sopan kepada guru. Hampir setiap kasus yang sama selalu dilakukan beberapa siswa yang sama, berdasarkan keterangan beberapa teman siswa yang sering tidak mengikuti aturan sekolah tersebut diluar sekolah juga mereka memiliki akhlak yang kurang baik dan sering terlibat pergaulan bebas, seperti sering pulang larut malam dan terlibat dalam minuman keras.

\section{Tinjauan Pustaka}

\section{A. Kerja Sama}

Kerja sama adalah pekerjaan yang dilakukan secara bersama antara dua atau lebih individu yang bertujuan agar pekerjaan menjadi lebih ringan. Iin Surmina (2013:101-102) mengemukakan kerja sama yaitu adanya keterkaitan antara seseorang dengan orang lain dengan maksud untuk mencapai penyelesaian masalah yang dialami. Berdasarkan paparan di atas maka dapat diketahui kerja sama berarti usaha bersama antara dua orang atau lebih untuk mencapai tujuan bersama demi memperoleh hasil yang diinginkan.

Dalam bekerja sama terdapat kelebihan dan kekurangan yang dimiliki oleh masingmasing pihak. Keduanya harus bisa menutupi kekurangan dengan kelebihan yang mereka miliki. Dalam hal ini hasil yang diperoleh diharapkan harus lebih baik dibanding dikerjakan secara sendiri.

H Kusnadi dalam Kusuma (2018:28) mengemukakan bahwa kerja sama memiliki beberapa manfaat yaitu:

1. Dalam mencapai tujuan dan meningkatkan produktivitas kerja sama dapat mendorong persaingan.

2. Kerja sama membuat individu berupaya agar bekerja efektif, produktif, dan efisien.

3. Dengan kerja sama akan tercipta sinergi sehingga biaya operasional lebih rendah mengakibatkan kemampuan bersaing meningkat. 
4. Dengan kerja sama membuat situasi lingkungan menjadi lebih baik.

Istilah guru dalam bahasa arab disebut mu'allim dan dalam bahasa inggris disebut teacher yang memiliki arti yang sangat sederhana yaitu a personhose occupation is teaching other, yang artinya yaitu orang yang profesinya mengajarkan orang lain. (Muhibbin Syah, 2010:222).

Menurut Rulan Ahmadi (2014:64), pendidik adalah orang yang bertanggung jawab atas pendidikan anak didik. Pihak yang bertanggung jawab atas pendidikan peserta didik adalah guru sekolah, orang tua dan masyarakat. Orang tua adalah pendidik di rumah, sedangkan guru adalah pendidik yang ada di sekolah.

Selanjutnya, Hari Priatna (2013:144) mengemukakan bahwa, guru merupakan faktor yang sangat penting dan dianggap sangat penting di dunia pendidikan juga dalam proses belajar. Pada saat yang sama proses dalam pembelajaran guru harus memiliki kemampuan yang unik agar mencapai harapan yang diharapkan dalam proses belajar mengajar.

Menurut Bafirman (2016:73-74) pakar pendidikan juga mengungkapkan bahwa guru berperan seperti:

1. Pendidik. Guru adalah seorang pendidik yang merupakan model untuk diikuti oleh para siswa, sebab itu guru wajib memiliki kriteria kualitas pribadi. Ini termasuk tanggung jawab otoritas dan disiplin.

2. Pengajar. Guru membantu mempelajari sesuatu yang tidak dapat ditemukan peserta didik dan memahami materi pengajaran. Perkembangan teknologi mengubah peran guru yang bertugas mengajar kepada orang yang bertanggung jawab untuk memberikan kemudahan untuk belajar.

3. Pembimbing. Guru membimbing peserta didik agar mereka melewati perkembangan emosi, mental, spiritual, kreatifitas, moral, dan mental secara benar.

4. Pelatih. Proses pembelajaran harus mengembangkan keterampilan intelektual, dan motorik peserta didik, sehingga guru bertindak sebagai orientasi peserta didik.

Orang tua adalah ayah dan ibu yang dikenal pertama oleh anak-anaknya. Orang tua menjadi pendidik pertama bagi anaknya karena orang tua yang menanamkan nilai pendidikan terhadap anaknya. Dengan itu pendidikan bersumber dari keluarga. Pendidikan berasal dari kesadaran dan naluri kodrati yang akan membangun situasi pendidikan. Situasi pendidikan dapat terbangun dari lingkungan yang baik yaitu lingkungan keluarga. Ayah dan ibu sebagai orang tua memiliki peran penting yang sangat mempengaruhi pendidikan anaknya.

Makna kata keluarga dapat ditinjau dari 2 dimensi yaitu hubungan darah dan hubungan sosial. Keluarga dalam dimensi hubungan darah merupakan suatu kesatuan yang diikat oleh hubungan darah antara satu dengan yang lainnya. Berdasarkan dimensi hubungan darah ini, keluarga dapat dibedakan menjadi kelurga besar dan keluarga inti. Keluarga adalah kelompok primer yang paling penting dalam masyarakat. Sedangkan dalam dimensi hubungan sosial, keluarga merupakan satu kesatuan yang diikat oleh adanya saling berhubungan atau interaksi dan saling mempengaruhi antara satu dengan lainnya, walaupun diantara mereka tidak terdapat hubungan darah (Saiful Bahri Djamarah, 2004:16).

Tanggung jawab orang tua dalam membina dan mendidik akhlak seorang anak sekurang-kurangnya yaitu: pertama, memelihara dan membesarka anak. Ini adalah bentuk yang paling sederhana dari tanggung jawab orang tua dan merupakan dorongan alami untuk mempertahankan kelangsungan hidup. Kedua, melindungi dan menjamin kesamaan baik jasmani maupun rohaniyah dari gangguan penyakit dan penyelewengan kehidupan dari tujuan hidup sesuai dengan falsafah hidup dan agama yang di anutnya. Ketiga, memberikan pengajaran dalam arti luas sehingga anak memperoleh pandangan dan peluang untuk memiliki pengetahuan dan kecakapan seluas dan setinggi mungkin yang dapat dicapainya. Keempat, membahagiakan anak, baik didunia maupun diakhirat sesuai dengan pandangan dan tujuan hidup muslim.

\section{B. Akhlak}


Rosidatul Haq dan Ahmad Kosasih: Kerja Sama Guru dan Orang Tua dalam Membina Akhlak...

Menurut Zuhairini akhlak adalah ilmu yang mempelajari perilaku atau sikap manusia dalam kehidupan bermasyarakat. (Zuhairini dkk, 2008:51). Imam Al-Ghazali menunjukkan bahwa akhlak merupakan karakteristik yang tertanam dalam jiwa dari perilaku, dapat dengan mudah muncul tanpa pertimbangan. (Zainuddin dkk, 2000:74).

Akhlakul karimah atau akhlak terpuji sangat penting bagi setiap orang, dimanapun mereka berada. Karena jika seseorang kurang dalam akhlak maka tidak akan dihargai dan dianggap tidak berpendididkan dan tidak beradab, bahkan dapat dianggap kurang dalam beretika. Untuk membentuk anak berakhlak mulia haruslah dibina secara berangsurangsur dan berkesinambungan, karena akhlak tidak dapat dibentuk satu atau dua hari saja dirumah, di sekolah, dalam masyarakat bahkan tidak dapat di bentuk sebulan atau setahun saja, melainkan harus dibentuk dalam seluruh tingkat kehidupan anak, tentunya diiringi dengan kebiasaan anak berakhlak baik serta diberi dorongan orang tua melaksanakan sesuatu yang baik.

\section{Metode}

Dalam penelitian ini menggunakan jenis penelitian Field Research (Penelitian Lapangan) dengan menggunakan metode penelitian kualitatif deskriptif. Penelitian lapangan (field research) bertujuan untuk mengetahui gejala-gejala yang terjadi di lapangan. Penelitian lapangan dapat juga dianggap sebagai pendekatan luas dalam penelitian kualitatif (Sugiyono, 2012). Metode penelitian kualitatif deskriptif yaitu metode penelitian yang berusaha membuat deskripsi dari fenomena yang diselidiki dengan cara menggambarkan atau melukiskan dan mengklasifikasikan atau karakteristik fenomena tersebut secara cermat, kemudian menjelaskannya dalam bentuk kesimpulan. Metode penelitian kualitatif deskriptif bertujuan untuk menggambarkan keadaan, status fenomena secara sistematis, dan akurat.

Lokasi penelitian ini adalah di SMA Negeri 1 Gunung Tuleh Kabupaten Pasaman Barat. Informan dalam penelitian ini adalah kepala sekolah, guru pendidikan agama islam (PAI) dan orang tua siswa SMA Negeri 1 Gunung Tuleh. Instrumen penelitian yang penulis gunakan adalah: handphone (untuk alat rekam serta camera sebagai bukti dokumentasi). Dalam penelitian ini teknik pengumpulan data yang digunakan adalah observasi, wawancara, dan dokumentasi. Teknik penganalisisan data yang digunakan yaitu reduksi data, penyajian data, penarikan kesimpulan dan verifikasi. Teknik pengabsahan yang digunakan dalam penelitian ini yaitu dengan menggunakan teknik triangulasi sumber. Teknik triangulasi sumber yaitu: mengecek data yang telah diperoleh melalui beberapa sumber.

\section{Hasil dan Pembahasan}

\section{A. Kerja Sama Guru dan Orang Tua dalam Membina Akhlak Siswa Kelas XII SMA Negeri 1 Gunung Tuleh Kecamatan Gunung Tuleh Kabupaten Pasaman Barat}

Kerja sama guru dan orang tua sangat penting dalam memberikan ilmu pengetahuan, membina dan mengembangkan peserta didik agar memiliki budi pekerti yang baik dalam segala segi kehidupan. Dengan demikian akan membentuk tingkah laku dan moral peserta didik yang memiliki budi pekerti untuk dikembangkan dalam kehidupan seharihari sehingga pada nantinya akan memiliki generasi muda yang memiliki aqidah yang kuat sehingga melahirkan akhlak yang baik dan mulia.

Dalam setiap keluarga atau orang tua berbeda-beda dalam mendidik anaknya. Dan orang tua menginginkan adanya patner untuk membantu mendidik anak-anak mereka yaitu dengan memasukkan anak ke sekolah. Karena baik orang tua maupun guru selalu berharap agar anak atau anak didiknya mampu mencapai prestasi dan tumbuh serta berkembang secara optimal. Oleh karena itu pendidik adalah tanggung jawab bersama antara keluarga, masyarakat, dan pemerintah. Guru hanyalah membantu kelanjutan pendidikan dalam keluarga sebab pendidikan yang pertama dan utama diperoleh anak adalah dalam keluarga. Sedangkan peralihan bentuk pendidikan jalur luar sekolah ke 
jalur pendidikan sekolah (formal) memerlukan "kerja sama" antara orangtua dan sekolah (pendidikan).

Sikap anak terhadap guru terutama akan dipengaruhi oleh sikap orang tuanya. Begitu juga sangat diperlukan kepercayaan orang tua terhadap sekolah (pendidik) yang menggantikan tugasnya selama diruangan sekolah. Hal ini sangat penting untuk diperhatikan, mengingat akhir-akhir ini seringnya terjadi tindakan-tindakan kurang terpuji dilakukan anak didik, sementara orangtua seolah tidak mau tahu, bahkan cenderung menimpakan kesalahan kepada guru. Orang tua harus memperhatikan sekolah anaknya, yaitu dengan memperhatikan pengalaman-pengalamannya dan menghargai segala usahanya. Begitu juga orang tua harus menunjukkan kerja samanya dalam mengarahkan cara anak belajar dirumah. Orang tua harus berusaha memotivasi dan membimbing anak dalam belajar. Bahkan berkat kerja sama orang tua anak didik dengan pendidik, banyak kekurangan anak didik yang dapat diatasi.

Untuk mewujudkan kerja sama itu tentunya banyak cara yang dilakukan, dengan adanya kerja sama itu orang tua akan dapat memperoleh pengetahuan dan pengalaman dari guru dalam mendidik anak-anaknya. Karena sekolah atau guru bukan hanya mengajar saja akan tetapi juga berusaha membentuk kepribadian anak menjadi manusia yang berakhlak baik sesuai dengan ajaran Islam.

Menurut Muhammad Zunni, S.Pd., MM, Kepala sekolah SMA Negeri 1 Gunung Tuleh (Wawancara, Kamis, 15 Juli 2021): "Pendidikan akhlak pada siswa sangat penting bukan hanya guru agama saja yang akan menanamkan sikap akhlak yang baik melainkan semua guru. Kerja sama orang tua dan guru dalam membina akhlak siswa di sekolah sudah terjalin dengan baik, misalnya dalam acara komite sekolah bahwa orang tua mau bekerja sama dengan sekolah untuk membina siswa agar menjadi siswa yang berilmu dan berakhlak baik, selain itu sekolah juga mempunyai kegiatan-kegiatan keagamaan, osis, pramuka dan lain-lain untuk pembinaan akhlak siswa. Kepala sekolah juga mengadakan seminar dan whorshop untuk guru dalam pendidikan akhlak siswa. Selain itu Kepala sekolah mengatakan upaya pembentukan akhlak siswa di sekolah dengan melakukan 3 (Tiga) M yaitu mulai dari sendiri, mulai dari yang kecil dan mulai dari sekarang. Namun ada beberapa faktor pendukung dan penghambat dalam upaya pembentukan akhlak siswa di sekolah. Faktor pendukung dalam upaya pembentukan akhlak siswa yaitu siswa seluruhnya beragam islam dan berlatang belakang sekolah agama. Sedangkan faktor penghambatnya yaitu sebagian besar siswa memakai Handphone (Hp), situasi dan kondisi saat ini berada pada masa pandemi Covid-19 dan kesadaran guru mapun siswa terhadap akhlak masih rendah. Untuk mengatasi hal tersebut kepala sekolah memberikan solusi berupa sosialisasi secara kontinue tentang pentingnya akhlak terhadap semua warga sekolah. Selain itu kepala sekolah juga memberikan solusi mendatangkan Da'i dan motivator dalam berbagai kegiatan sekolah".

Berdasarkan hasil dari wawancara dan observasi yang telah peneliti lakukan diperoleh informasi bahwa, pada umumnya kerja sama antara guru dan orang tua dalam membina akhlak siswa kelas XII SMA Negeri 1 Gunung Tuleh Kecamatan Gunung Tuleh Kabupaten Pasaman Barat sangat penting. Hal ini dibuktikan dengan adanya orang tua yang berkonsultasi dan berkomunikasi dengan guru disekolah untuk mengetahui bagaimana akhlak anaknya selama berada disekolah. Begitu juga siswa di SMA Negeri 1 Gunung Tuleh rata-rata memiliki akhlak yang baik, baik kepada guru maupun kepada orang tua.

Namun di antara siswa SMA Negeri 1 Gunung Tuleh, ada yang masih suka Berbicara tidak sopan kepada guru dan membantah serta membangkang apa yang diperintahkan oleh orang tua di rumah.

Adapun akhlak siswa kepada orang yang lebih tua dapat tergambar dari cara mereka berkomunikasi dengan menggunakan bahasa yang baik dan sopan. Umumnya bisa menggunakan bahasa yang baik dan sopan apabila berbicara dengan orang yang lebih tua. Hal ini menunjukan bahwa dalam diri siswa mulai tumbuh rasa hormat dan 
Rosidatul Haq dan Ahmad Kosasih: Kerja Sama Guru dan Orang Tua dalam Membina Akhlak...

menghargai orang yang lebih tua. Adanya siswa yang masih belum menggunakan bahasa yang baik dan sopan apabila berbicara dengan yang lebih tua, hal ini disebabkan dalam pergaulan makna bahasa sering mengalami pergeseran.

Adapun akhlak siswa kepada guru antara lain diwujudkan dengan kebiasaan menyapa dan memberi salam bila bertemu dengan guru. Perasaan siswa kepada guru merupakan bagian penting dari perasaan mereka terhadap sekolah secara keseluruhan, guru yang baik dihormati dan diteladani siswa. Pada umumnya sangat hormat kepada guru. Mereka tahu bahwa mereka mendapat ilmu pengetahuan berkat bimbingan dari gurunya. Dari gurulah mereka mendapat penjelasan tentang apa-apa yang tidak bisa dipahaminya sendiri. Adapun mengenai siswa yang hanya menegur tanpa memberi salam bila bertemu guru, hal ini mungkin karena mereka belum memahami sepenuhnya keutamaan dan hikmah salam.

\section{B. Upaya yang Dilakukan Guru dan Orang Tua dalam Mengatasi Hambatan Pembinaan Akhlak Siswa SMA Negeri 1 Gunung Tuleh Kecamatan Gunung Tuleh Kabupaten Pasaman Barat}

Pembinaan akhlak tidak dapat dilakukan secara spontanitas sebagaimana terbentuknya prilaku berakhlak, namun memerlukan perencanaan, pembinaan, pengevaluasian dan perhatian secara kontinyu oleh seluruh komponen pembentuk tingkah laku. Orang tua, dalam hal ini yang berada dalam lingkungan rumah tangga adalah merupakan orang yang memberikan dan meletakkan pendidikan yang pertama bagi seseorang. Dengan demikian, orang tua atau rumah tangga sering dikatakan sebagai lingkungan pendidikan yang pertama dan utama. Pertama mengandung pengertian bahwa setiap siswa yang lahir yang dibesarkan selalu dimulai dari lingkungan rumah tangga, dalam hal ini adalah orang tua. Sedangkan pendidikan utama mengandung makna bahwa orang tua menjadi peletak dasar-dasar pendidikan dan akhlak bagi siswa. Di samping orang tua di rumah, guru di sekolah juga memegang peranan penting dalam upaya pembinaan akhlak siswa di sekolah. Guru yang melanjutkan dan mengembangkan dasar-dasar akhlak yang telah diperoleh siswa di lingkungan keluarga dan masyarakat umum. Norma-norma, aturan-aturan, dan berbagai bentuk adat dan kebudayaan yang telah diperoleh siswa di dalam lingkungan pendidikan siswa yang pertama, dalam hal ini rumah tangga seyogyanya dilanjutkan dan dikembangkan pembinaannya di lingkungan sekolah.

Antara pendidikan rumah tangga dengan pendidikan sekolah harus memiliki program yang integratif (integratif program) yang tidak dapat dipisahkan antara satu sama lain. Peranan guru yang lain adalah harus mampu membaca dan melihat setiap potensi yang dimiliki setiap siswa untuk melanjutkan dikembangkan ke arah yang lebih optimal. Guru harus mampu memahami setiap perbedaan siswa. Keragaman pelajaran harus menjadi perhatian guru di sekolah. Perhatian dan keragaman tersebut akan berefleksi pada pemberian muatan akhlak yang sesuai dengan kebutuhan setiap siswa. Dengan demikian peranan guru dalam membantu mengembangkan akhlak yang baik dapat dijalankaan secara optimal.

Ada berbagai peranan perlu dimainkan guru dalam upaya pembentukan akhlak siswa, antara lain memasukkan muatan ajaran mengenai akhlak, pemberian contoh-contoh yang baik, memberi contoh kedisiplinan waktu, mengarahkan dalam arti memodifikasi tingkah laku siswa yang tidak mencerminkan akhlak yang baik, mengontrol sikap dan tingkah laku siswa selama berada dalam lingkungan sekolah, mengadakan komunikasi secara intens dengan keluarga siswa tentang keadaan dan perkembangan siswanya di sekolah begitupun sebaliknya orang tua mencari tahu tentang perkembangan anaknya di sekolah.

Beberapa upaya - upaya tersebut antara lain:

1. Orang tua dan guru harus memberikan perhatian khusus kepada anak-anaknya, dan bagi guru dan khususnya orang tua harus berusaha agar dapat meluangkan waktunya 
secara khusus untuk memberikan pembinaan akhlak kepada anak dan mengawasi kegiatan anak.

2. Diberikan pengetahuan kepada orang tua murid bahwa pembinaan akhlak anak itu sangat penting.

3. Orang tua seharusnya diberi pemahaman bahwa pembinaan akhlak dirumah menjadi salah satu faktor utama bagi anak.

4. Untuk menanggulangi ketaatan anak yang kadang-kadang tidak patuh pada perintah guru dan orang tua, maka solusi yang dilakukan oleh guru dan orang tua menasehati anak-anak dan juga menggunakan metode hadiah dan sanksi.

5. Untuk menanggulangi kesadaran guru dalam mencerminkan prilaku yang baik ketika mengajar di kelas dan kesadaran orang tua dalam mencerminkan prilaku yang baik ketika mengajar di rumah, maka solusi yang dilakukan oleh guru dan orang tua adalah menginstrospeksi diri dengan mengingat tugas dan tanggung jawab sebagai guru dan orang tua bagi siswa.

6. Untuk mengatasi keadaan lingkungan yang kurang mendukung, maka orang tua berusaha untuk mendidik sendiri dan juga memantau pergaulan anak di lingkungan sekitar rumah. Hal ini dilakukan karena adanya kepedulian orang tua terhadap anakanaknya dan agar interaksi antara orang tua dan anak terjalin dengan baik, sehingga anak merasa bahwa orang tua masih memperhatikannya.

7. Tingkat pengetahuan agama sebagian orang tua masih rendah merupakan salah satu faktor yang menghambat pembinaan akhlak dalam keluarga. Oleh karena itu, pengetahuan agama orang tua harus lebih ditingkatkan, agar orang tua dapat memberikan pengetahuan agama secara optimal kepada anak, dengan cara meluangkan waktunya untuk menghadiri pengajian yang dilaksanakan oleh majlis ta'lim dan kegiatan-kegiatan keagamaan lainnya.

\section{Simpulan}

Kerja sama dalam pembinaan akhlak siswa sangat penting. Hal ini akan sangat berpengaruh terhadap pembinaan akhlak siswa, oleh karena itu tentu dibutuhkan kerja sama antara satu dengan yang lain, hal ini dimaksudkan agar orang tua dan guru dengan mudah memahami bagaimana membina akhlak siswa supaya memiliki akhlak yang mulia. Adapun kerja sama yang dilakukan oleh guru dan orang tua dalam pembinaan akhlak siswa pada SMA Negeri 1 Gunung Tuleh Kecamatan Gunung Tuleh Kabupaten Pasaman Barat adalah orang tua melakukan konsultasi langsung pada guru atau sebaliknya guru melakukan konsultasi kepada orang tua serta orang tua melakukan kunjungan ke sekolah,

Pada umumnya SMA Negeri 1 Gunung Tuleh Kecamatan Gunung Tuleh Kabupaten Pasaman Barat memiliki akhlak yang baik, hal itu dibuktikan dengan cara mereka berkomunikasi dengan menggunakan bahasa yang baik dan sopan kepada orang yang lebih tua, memliki kebiasaan menyapa dan memberi salam bila bertemu dengan guru, hormat dan patuh kepada guru dan orang tuanya.

Upaya-upaya yang dilakukan oleh guru dan orang tua dalam mengatasi hambatan yang dihadapi dalam pembinaan akhlak siswa pada SMA Negeri 1 Gunung Tuleh Kecamatan Gunung Tuleh Kabupaten Pasaman Barat antara lain guru dan orang tua harus memberikan perhatian khusus kepada anak-anaknya dalam hal pembinaan pendidikan agama Islam dan bagi guru dan khususnya orang tua harus berusaha agar dapat meluangkan waktunya secara khusus untuk memberikan pembinaan akhlak kepada anak dan mengawasi kegiatan anak, diberikan pengetahuan kepada orang tua murid bahwa pendidikan agama anak itu sangat penting, orang tua seharusnya diberi pemahaman bahwa pembinaan pendidikan agama anak khususnya pembinaan akhlak dirumah menjadi salah satu faktor utama dalam pembinaan pendidkan agama anak, menasehati anak-anak dan juga menggunakan metode hadiah dan sanksi, guru dan orang tua adalah menginstrospeksi diri dengan mengingat tugas dan tanggung jawab sebagai guru dan orang tua bagi siswa, memantau pergaulan anak di 
Rosidatul Haq dan Ahmad Kosasih: Kerja Sama Guru dan Orang Tua dalam Membina Akhlak...

lingkungan sekitar rumah dan pengetahuan agama orang tua harus lebih ditingkatkan, agar orang tua dapat memberikan pengetahuan agama secara optimal kepada anak.

\section{Referensi}

Daradjat, Zakiyah. (1992). Ilmu Pendidikan Islam. Jakarta: Bumi Aksara.

Darmadi, H. (2016). Tugas, Peran, Kompetensi, Dan Tanggung Jawab Menjadi Guru Profesional. Edukasi: Jurnal Kependidikan, 13(2), 161-174.

Djamarah, Bahri Syaiful. (2004). Pola Komunikasi Orang Tua \& Anak Dalam Keluarga. Jakarta: PT Rineka Cipta.

Faridatul Khoiriyah, L. (2017). Skripsi. Kolaborasi Orang Tua Dan Guru Dalam Pencegahan Pergaulan Bebas Peserta Didik Di Home Schooling Group Khoirul Ummah Malang.

Hasbullah. (2009). Dasar-Dasar Ilmu Pendidikan. Jakarta: PT Grasindo Persada.

Iin Surmina. (2013). Pola Kerja sama Lembaga Dengan Pengguna Dalam Manajemen Litbang. Vol 5 No 2.

Lestari \& Alauddin. (2018). Jurnal. Pola Komunikasi Guru Dan Orang Tua Dalam Pembinaan Akhlak Peserta Didik.

Ramayulis. (2013). Profesi Dan Etika Keguruan. Jakarta: Kalam Mulya.

Saleh, Abdurrahman dkk. (2004). Psikologi Suatu Pengantar dalam Prespektif Islam. Jakarta: Kencana.

Sugiyono. (2012). Metode Penelitian Pendidikan Pendekatan Kuantitatif, Kualitatif Dan R\&D. Bandung: Afabeta.

Syah, Muhibbin. (2010). Psikologi Pendidikan Dengan Pendekatan Baru. Bandung: PT Remaja Rosdakarya. 